\title{
Analisis Permodalan Buruh Tenun Tradisional Bima Pada Tenun Tembe Nggoli
}

\author{
Nurnazmi ${ }^{1}$ Syaifullah $^{2}$ \\ Program Studi Pendidikan Sosiologi STKIP Bima \\ Jalan Piere Tendean Kel. Mande Tlp.Fax (0374) 42801, Bima 84191, Indonesia \\ (Email: syaifullahsosiologi@gmail.com)
}

\begin{abstract}
Abstrak
Permodalan buruh tenun yakni sumber modal yang akan dijalankan untuk mengoperasionalkan hasil produksi untuk berdaya guna pada penenun yang memiliki modal kerja seperti tenaga dan peralatan produksi, sehingga tenaga yang dikeluarkan oleh penenun dapat diberikan upah berupa uang atau barang (benang) untuk modal awal menenun. Hasil produksi akan di jual kepada perusahaan kain tenun. Tembe Nggoli merupakan salah satu jenis bahan kain tenun yang memiliki ukuran lebih kecil dan lembut, dan bahannya setelah ditenun akan menyesuaikan cuasa suhu kainnya, bisa dalam keadaan dingin disaat cuaca panas dan kainnya akan hangat pada cuaca dingin. Tujuan penelitian untuk mendeskripsikan permodalam buruh tenun tradisional Bima pada buruh tembe nggoli. Analisis temuan penelitian menggunakan teori tindakan Sosial Max Weber. Hasil penelitian menunjukkan permodalan dapat bersumber pada modal sendiri penenun tersebut, modal tenun bersumber pada perusahaan/ UMKM, modal tenun bersumber dari koperasi dan modal tenun bersumber pada bank.
\end{abstract}

Kata Kunci : Permodalan, Buruh Tenun, Tembe Nggoli

\begin{abstract}
Weaving labor capital is a source of capital that will be run to operationalize the production results to be effective in weavers who have working capital such as labor and production equipment, so that the energy released by the weaver can be given wages in the form of money or goods (yarn) for initial capital weaving. Production will be sold to woven fabric companies. Tembe Nggoli is one type of woven fabric that has a smaller size and is soft, and the material after weaving will adjust the temperature of the cloth fast, can be cold when hot weather and the fabric will be warm in cold weather. The purpose of this research is to describe the permits of Bima traditional weaving workers in Tembe Nggoli workers. Analysis of research findings using Max Weber's theory of social action. The results showed that capital can be sourced from the weaver's own capital, weaving capital sourced from companies / UMKM, weaving capital sourced from cooperatives and weaving capital sourced from banks.

Keywords: Capital, Weaving Workers, Tembe Nggoli
\end{abstract}




\section{Pendahuluan}

Kerajinan tenun tradisional adalah bagian dari seni budaya tradisional adalah bagian dari seni budaya tradisional yang dapat ditemukan di seluruh wilayah Indonesia. Biasanya kerajinan tenun tradisional ini dilestarikan secara turun temurun yang menjadi salah satu warisan nenek moyang yang sangat berharga. Dari berbagai daerah tenun tradisional Indonesia memiliki kekayaan motif dan keunikan bentuk, baik pada pemakaian bahan maupun pewarnaan alam masingmasing daerah memiliki warna etnik tersendiri (Alimuddin Meisr, 2010: 2).

Tenun merupakan hasil kerajinan yang berupa bahan kain yang dibuat dari benang, serta kayu, sutra dan lain-lain. Pembuatannya dengan menggunakan seperangkat alat tenun tangan atau biasa disebut lungsin. Lungsin adalah jajaran benang yang terpasang membujur (MR Pahlevi Putra N.I Singke, 2011: 16).

Songke biasanya suku Mbojo menyebut kain tradisional suku Mbojo karena jenis kain yang ditenun berupa jenis tenun songket. Tenun songket suku Mbojo merupakan kumpulan dari benang emas dan benang perak yang dipadatkan atau dirapatkan dengan cara di tenun atau $d i$ muna sehingga menghasilkan selembar kain tenun MR Pahlevi Putra N.I Singke, 2011: 17).

Pengrajin kain tenun songket tradisional Bima tembe nggoli terdapat di beberapa Kelurahan di Kota Bima, antara lain: Kelurahan Rabadompu Barat Kecamatan Raba, Kelurahan Rabadompu Timur Kecamatan Raba, Kelurahan Ntobo Kecamatan Raba, Kelurahan Oi Fo'o Kecamatan Rasana'e Timur, Kelurahan Nitu Kecamatan Rasana'e Timur, Kelurahan Lelamase Kecamatan Rasana'e Timur, Kelurahan Nungga Kecamatan Rasana'e Timur. Peneliti melakukan penelitian pada Kelurahan Rabadompu Barat Kecamatan Raba, sebagaimana data jumlah penenun sebagai berikut:
Tabel 1.1 Data Penenun di Kelurahan Rabadompu Barat Kecamatan Raba

\begin{tabular}{|c|l|r|}
\hline No. & Nama Kampung & $\begin{array}{c}\text { Jumlah } \\
\text { Buruh } \\
\text { Tenun }\end{array}$ \\
\hline 1 & Temba & 32 orang \\
\hline 2 & Rato & 26 orang \\
\hline 3 & Dewakeu & 26 orang \\
\hline 4 & Kota baru & 40 orang \\
\hline 5 & Naru & 59 orang \\
\hline 6 & Tere & 7 orang \\
\hline
\end{tabular}

Sumber : Nurnazmi, Syaifullah dan Ida Waluyati, 2019, Pola Hubungan antara Buruh Tenun (Tembe Nggoli) dengan Pemilik Modal di Kelurahan Rabadompu Barat Kecamatan Rana Kota Bima, Hal: 249250.

Penenun dikategorikan dalam 3 kelompok yakni penenun atau buruh tenun tembe nggoli, penenun atau buruh tenun galendo dan penenun atau buruh tenun mesrai. Jumlah penenun atau buruh tenun tembe nggoli sejumlah 49 orang atau $29 \%$ dari jumlah 172 orang penenun atau buruh tenun di Kelurahan Rabadompu Barat Kecamatan Raba Kota Bima.

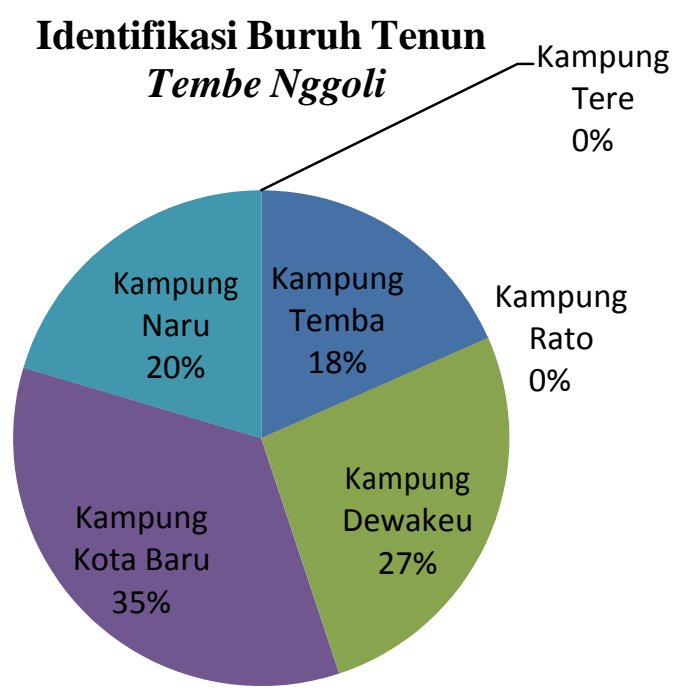


Modal adalah dana yang diserahkan oleh para pemilik. Pada akhir tahun buku, setelah dihitung keuntungannya yang didapat pada tahun tersebut, pemilik modal akan memperoleh bagian dari hasil usaha yang biasa dikenal dengan deviden. Dalam modal dapat digunakan untuk pembelian gedung, tanah, perlengkapan dan sebagainya yang secara langsung tidak menghasilkan. Selain itu juga modal dapat digunakan untuk hal-hal yang produktif, yaitu disalurkan menjasi pembiayaan yang berasal dari modal, hasilnya tentu saja di bagi pemilik modal, tidak dibagikan kepada pemilik dana lainnya (Antonio, 2004 dalam Rahmat Ilyas, 2017: 326). Permasalah modal inilah yang terjadi dari sumber atau pemilik modal dengan penenun atau buruh tenun, dimana adanya keuntungan yang sangat inheren dalam proses perdagangan. Modal yang diberikan oleh pemilik modal seperti perusahaan kain tenun tradisional Bima yang diberikan kepada penenun atau buruh tenun lebih murah harga jual kainnya dibandingkan dijual langsung oleh penenun kepada konsumen. Sehingga mendorong penenun atau buruh tenun membuat pola baru dalam permodalan yakni meminjam pada perbankan, koperasi atau bahkan pada rentenir.

\section{Metode Penelitian}

Pendekatan dalam penelitian ini yakni pendekatan kualitatif, metode penelitian deskripsi, penelitian deskripsi adalah suatu bentuk penelitian yang paling dasar, yang ditujukan untuk mendeskripsikan fenomena-fenomena yang ada, baik fenomena yang bersifat alamiah ataupun rekayasa manusia (Nana Syaodah Sukmadinata, 2011: 72).

Teknik pengumpulan data menggunakan observasi dan wawancara. Observasi merupakan observasi yang didalamnya peneliti langsung turun di lapangan untukmengamati perilaku atau aktivitas individu-individu di lokasi penelitian (John W.Creswell, 2012: 267).

Jenis observasi yang digunakan yakni observasi non-partisipan dan sistemik (Usman, Ahmad, 2008: 290-291). Pengambilan data dengan wawancara, peneliti menggunakan wawancara terstruktur (Darmadi. Hamid, 2013: 306-307). Wawancara terstruktur adalah wawancara yang dilakukan dengan menggunakan pedoman wawancara yang telah disusun secara sistematis dan lengkap untuk mengumpulakn data (Eko Putro Widoyoko, 2012: 42). Dokumentasi yakni memperole database penenun di Kelurahan Rabadompu Barat Kecamatan Raba Kota Bima.

Mile dan Huberman dalam Sugiyono (2010: 246-252) mengemukakan bahwa aktivitas dalam analisis data kualitatif dilakukan secara interaktif dan berlangsung secara terus menerus sampai tuntas, sehingga datanya sudah jenuh. Aktivitas dalam analisis data, yaitu: reduksi data (data reduction), penyajian data (data display) dan ferivikasi data (conclusion drawing/ verification). Pengujian keabsahan data menggunakan triangulasi, triangulasi diartikan sebagai teknik pengumpulan data yang bersifat menggabungkan dari berbagai teknik pengumpulan data dan sumber data yang telah ada. Bila peneliti melakukan pengumpulan data dengan triangulasi, maka sebenarnya peneliti mengumpulkan data yang sekaligus menguji kredibilitas data, yaitu mengecek kredibilitas data dengan berbagai teknik pengumpulan data dan berbagai sumber data (Sugiyono, 2010: 241-242).

\section{Hasil Penelitian}

\section{Pengertian Permodalan}

Menurut Schwiedland dalam Pieter Lienen (2012) dikutip oleh Wildan Yoga Baskara (2018: 2) memberikan pengertian modal dalam arti luas dimana modal itu meliputi dalam bentuk uang maupun bentuk barang.

Devinisi permodalan dari bank yakni menurut Wisnu Mawardi dalam Lukman Dendawijaya (2005) aspek permodalan diproksikan melalui rasio Capital Adequacy Ratio (CAR). Rasio ini juga dapat digunakan untuk menilai kecukupan modal yang dimiliki oleh bank (Dito 
nanda Supraba, 2010: 8). Permodalan adalah pengukuran terhadap besarnya jumlah modal yang dimiliki bank, sehingga mencerminkan besarnya sumber dana untuk membiayai operasional perusahaan (Kasmir, 2012 dalam Retna Atika Sari, 2017: 5). Permodalan dalam perbankan dapat diukur rasio Capital Adequacy Ratio (CAR) yaitu kecakupan modal yang menunjukkan kemampuan bank dalam mempertahankan modal yang mencakup kemampuan manajemen bank dalam mengidentifikasi, mengukur, mengawasi, dan mengontrol risiko-risiko yang dapat berpengaruh terhadap besarnya modal bank.

\section{Pengertian Buruh Tenun Tembe Nggoli}

Buruh tenun merupakan pekerjaan wanita paruh waktu (pekerjaan sampingan), yang dimana pekerjaan ini bermodalkan jasa karena biaya produksi bersumber dari pemiliki modal. Tembe nggoli merupakan salah satu jenis sarung songket tradisional Bima, yang bahan dasarnya dari benang nggoli (benang yang tipis dala artian urutan ke-dua dari benang mesrai dan di atas benang galendo) (Nurnazmi, Syaifullah dan Ida Waluyati, 2019: 250).

Buruh tenun tembe nggoli adalah seorang perempuan yang memiliki profesi sebagai pekerja yang menerima upah kerja pada awal proses penenunan belum dimulai atau upah awal dapat berupa uang atau benang, yang dimana pekerja wanita tersebut dapat menenun kain tenun songket tradisional Bima dengan warna biru muda, biru dongker, coklat, merah dan kuning serta warna yang lain sebagai warna pendukung, dengan motif yang timbul di atas kain tenun (Nurnazmi, Syaifullah dan Ida Waluyati, 2019: 245).

\section{Komparasi Tembe Nggoli dalam Perbedaan Lokasi Produksi}

Tembe merupakan barang unggulan yang dihasilkan oleh penenun. Selain untuk diperjual oleh masyarakat lokal, juga menjadi salah satu jenis barang yang laris dalam perdagangan Nusantara, terutama era Kesultanan sampai dengan Tahun 1960-an (Alan Malingi, 2010: 5).
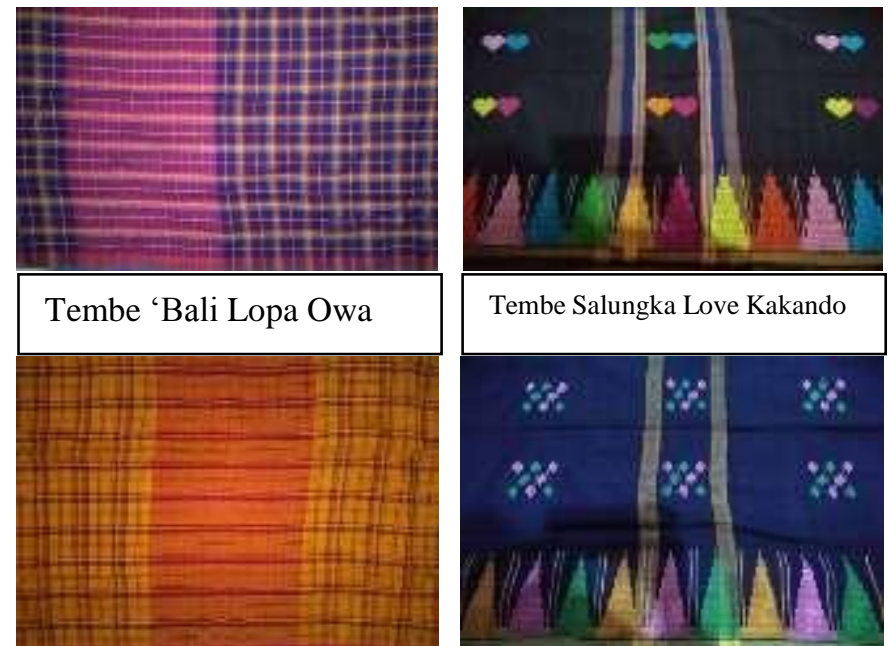

Tembe Salungka Love Kakando

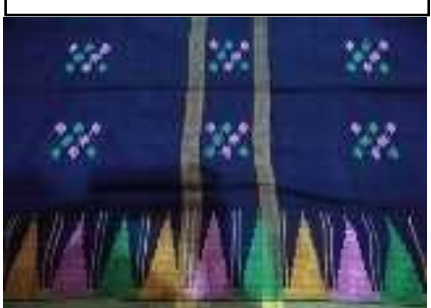

Tembe 'Bali Kere Capi

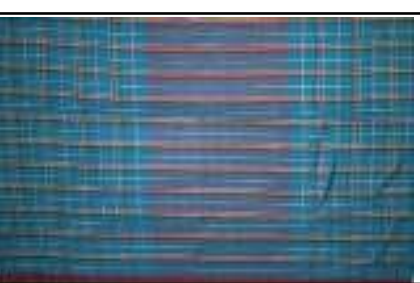

Tembe Salungka Jinta Kakando

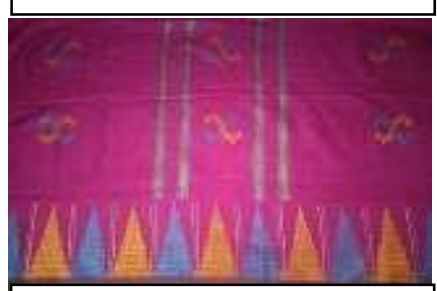

Tembe 'Bali Lopa Bako

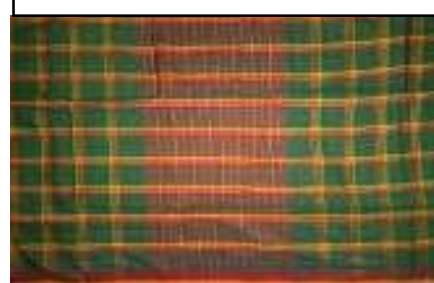

Tembe 'Bali Lopa Jao

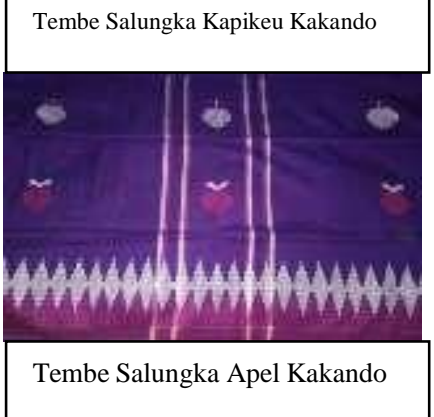


Dalam kewilayahan masyarakat samasama melakukan menenun dengan menggunakan bahan dasar Nggoli tetapi memiliki corak dan motif kain tenun yang berbeda-beda, sama halnya dengan contoh kain di atas. Kain tenun yang menjadi sampel dalam research ini menggunakan komparasi tembe nggoli yang ditenun oleh penenun dari Kelurahan Rabadompu Barat Kecamatan Raba dan Kelurahan Ntobo Kecamatan Raba.

Wilayah Kelurahan Rabadompu Barat Kecamatan Raba Kota Bima dikenal dengan tembe nggoli 'Bali dan tembe nggoli Lomba, dengan berbagai corak atau lopa yang bervariasi, mulai dari warna yang cerah sampai warna yang gelap. Warna yang digunakan yakni warna cerah seperti ungu, merah, biru dongker, hijau, pink, kuning, merah bata, coklat dan hitam. Tembe 'Bali mpida dan tembe Lomba termasuk dalam bentuk tembe kafa na'e. Tembe Bali Mpida bermotif garisgaris lurus kecil, yang akan membentuk kotak-kotak segi empat ukuran kecil. Karena itu, tembe kafa na'e diberi nama tembe bali mpida (bermotif garis kecil). Warna dasar (dana atau bahan di ngane) berwarna hitam, coklat dan putih. Tembe Lomba adalah tembe kafa na'e yang motifnya berupa garis-garis lurus yang besar dan akan membentuk kotak-kotak yang besar pula. Warna dasar (dana atau bahan di ngane) sama dengan warna dasar tembe bali (Alan Malingi, 2010: 6-7).

Wilayah Kelurahan Ntobo Kecamatan Raba Kota Bima, memilikicorak polos dengan motif yang sangat cerah, seperti pink, biru dongker, orange, ungun, hijau, merah, dan warna gelap (coklat dan hitam). Motif yang digunakan biasanya memiliki unsur flora dan fauna. Motif flora terdiri dari burung merpati, sawa maliwa dan garuda berkepala dua, kapikeu, wanga sahe, gigi anjing sedangan motif fauna terdiri dari tumbuh-tunbuhan kakando, pria, tomat, apel, pria double, bunga pot, ro'o wau. Selain itu, terdapat berbagai motif kain tenun tingkat motif modif, seperti pure, jinta, love, kotak suata.

\section{Permodalan Buruh Tenun Tembe Nggoli}

\section{a. Modal Tenun Bersumber dari Penenun atau Buruh Tenun}

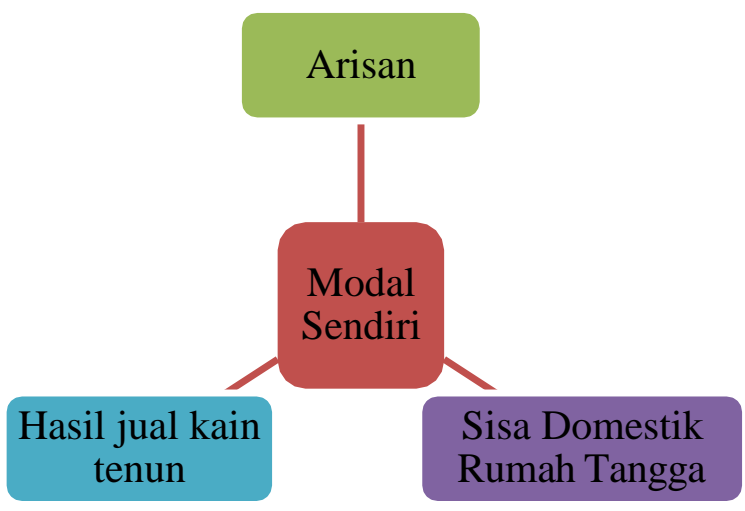

Skema 1.1 Sumber Modal Tenun dari Modal Sendiri

Modal tenun dapat bersumber dari penenun atau buruh tenun itu sendiri, baik bersumber dari sisa uang dari kebutuhan rumah tangga, hasil penjualan kain tenun terdahulu, dan uang arisan. Permodalan bersumber dari penenun itu sendiri tidak selamanya dapat dipertahankan karena dipengaruhi oleh berbagai faktor, sehingga dibutuhkan beberapa persiapan alternatif untuk cadangan modal tenun.

Pietra Sarosa (2004) memcari alternatif permodalan, dengan memperhitungkan hal-hal berikut:

1) Langkah awal mempersipakan modal, yang perlu diperhatikan berkaitan dengan modal, yaitu:

a) Hitung kebutuhan Modal

Untuk memulai sesuatu usaha maka harus diperhitungkan beberapa besarnya kebutuhan modal, baik modal kerja (biasanya modal awal berkoperasi) maupun kebutuhan modal keseluruhan. 
b) Siapkan Modal

Menyiapkan modal yang dibutuhkan tidaklah mudah, apalagi bila perusahaan atau wirausaha tidak mampu menyediakan modal sendiri yang besar yang dapat memenuhi semua di luar modal sendiri. Pietra Sarosa (2004) dalam Neti Budiwati, memberi cara untuk menyiasati kebutuha modal usaha yakni menekan modal, mengatur prioritas modal dan jagalah kepercayaan yang diberikan pihak lain kepada individu/ perusahaan.

c) Siapkan Dana Cadangan untuk 612 bulan ke depan

Perusahaan yang baru biasanya tidak langsung memperoleh laba yang dapat digunakan sebagai modal selama perusahaan beroperasi, sedangkan kebutuhan perusahaan tidak dapat ditunda. Oleh karena itu, perusahaan harus dapat menyediakan dana cadangan untuk memenuhi kebutuhan modal selama perusahaan belum dihasilkan (misalnya untuk 6 sampai 12 ke depan).

2) Sumber-Sumber Permodalan

Untuk memebuhi kebutuhan modal maka ada beberapa sumber permodakan yang dapat dijadikan sebagai alternative sumber modal, yaitu: (a) Modal sendiri adalah modal yang biasanya beradal dari pemilik,

(b) Modal pinjaman adalah yang berasal dari pihak atau kreditur baik bank atau lembaga keunagan bukan bank, dan (c) Modal ventura adalah modal yang diperoleh dari kerjasama dengan pihak lain.

\section{b. Modal bersumber dari Perusahaan/ UMKM}

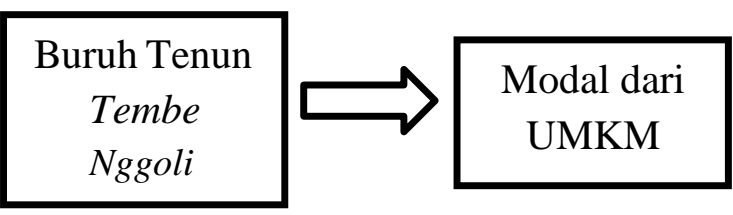

\section{Skema 1.2 Sumber Modal dari Perusahaan/ UMKM}

Sektor UMKM (Usaha Mikro Kecil dan menengah) yang mampu tetap berdiri kokoh. Data Badan Pusat Statistik merilis keadaan tersebut pasca krisis ekonomi jumlah UMKM tidak berkurang, justru meningkat pertumbuhannya teruas, bahkan mampu menyerap 85 juta hingga 107 juta tenaga kerja sampai tahun 2012. Pada tahun itu jumlah pengusaha di Indonesia sebanyak 56.539.560 unit. Dari jumlah tersebut, UMKM sebanyak 56.534.592 unit atau sebesar 99,99\%. Sisanya sekitar $0,01 \%$ atau sebesar 4,968 unit adalah usaha bersakala besar. Fenomena ini menjelaskan bahwa UMKM merupakan uasaha yang produktif untuk dikembangkan bagi pendukung perkembangan ekonomi secara makro dan mikro di Indoensia dan memepengaruhi sector-sektor yang lain bisa berkembang. Salah satu sector yang berpengaruh dari UMKM adalah sector jasa perbank yang ikut terpengaruh, sebab hamper $30 \%$ usaha UMKM mengunakan modal operasional dari perbankan (Yuli Rahmini Suci, 2017: 51).

\section{c. Modal bersumber dari Koperasi}

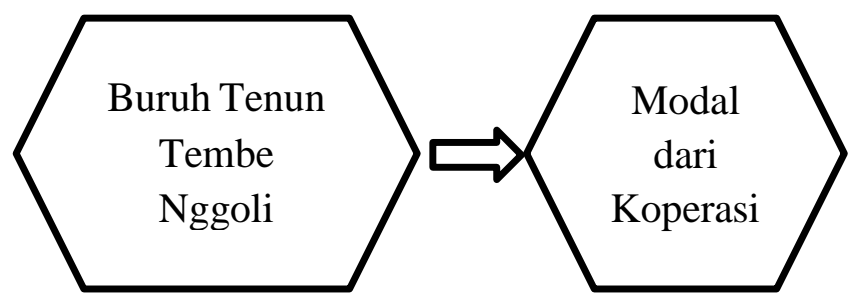

Skema 1.3

Sumber Modal dari Koperasi 
Koperasi merupakan salah satu badan usaha, disamping badan usaha lain seperti BUMN, BUMD, maupun badan usaha swasta seperti Perseroan terbatas, CV, UD dan lainnya (Sigit Puji Winarko, 2014: 152). Berdasarkan UU RI Nomor 25

Tahun 1992 tentang Koperasi Pasal 41 Ayat 1 bahwa modal koperasi terdiri dari modal sendiri dan modal pinjaman. Modal sendiri adalah modal yang menangung resiko atau disebut modal ekuiti, yang terdiri dari simpanan pokok, simpanan wajib dan dana cadangan.

Sesuai dengan Undang-Undang No.17 Tahun 2012 Tentang Perkoperasian Pasal 26 Ayat 1 bahwa: anggota koperasi merupakan pemilik dan sekaligus pengguna jasa koperasi. Sehingga koperasi ini tidak dimiliki oleh perorangan, melainkan dimiliki oleh keseluruh anggota koperasi dan pasar dari koperasi adalah anggotanya sendiri yang tidak melayani luar anggota. Jadi koperasi merupakan badan usaha yang dibentuk untuk memenuhi kebutuhan anggotanya, demi kemakmuran dan kesejateraan bersama, tidak seperti badan usaha lainnya yang melayani masyarakat secara umum. Peminjaman modal yang dilakukan oleh penenun atau buruh tenun hanya berperan sebagai anggota koperasi yang hanya membayarkan kewajibannya pinjamannya kepada koperasi tersebut tanpa mengetahu lebih jauh tentang Anggaran dasar dan Anggaran Rumah Tangga serta keputusan yang telah disepakati dalam rapat (yang terjadi penenun dan pegawai koperasi tidak pernah merapatkan tentang apa yang akan penenun atau buruh tenun lakukan akan tetapi yang diketahui oleh penenun membayar jumlah tagihan setiap harinya/ tiap minggunya atau tiap bulannya).

Posisi penenun atau buruh tenun dalam proses peminjaman modal dalam koperasi lebih mengarah pada koperasi sebagai pemilik modal, yang memberikan pinjaman modal pada penenun, yang dimana penenun tidak dijadikan sebagai anggota koperasi tetapi peminjam modal. Koperasi itu sendiri lebih menempatkan posisinya sebagai media untuk pengembalian modal, sehingga tidak ada asas kekeluargaan dalam koperasi terebut, dan tidak ada pemenuhan atas hak-ahak anggota koperasi, seperti: menghadiri, menyatakan pendapat, dan memebrikan suaradalam rapat anggota; memilih dan/atau dipilih menjadi anggota pengurus atau pengawas; Meminta diadakan rapat anggota menurut ketentuan dalam anggaran dasar; Mengemukakan pendapat atau sarana kepada pengurus di luar pada anggota baik diminta amaupun tidak diminta; memanfaatkan koperasi dan mendaptkan pelayanan yang sama antara sesame anggota; dan Mendapatkan keterangan mengenai perkembangan koperasi menurut ketentuan dalam anggaran dasar (UU RI No.17 Tahun 2012 Tentang Koperasi Pasal 20 ayat 2 pembahasan tentang Hak anggota).

\section{d. Modal bersumber dari Bank}

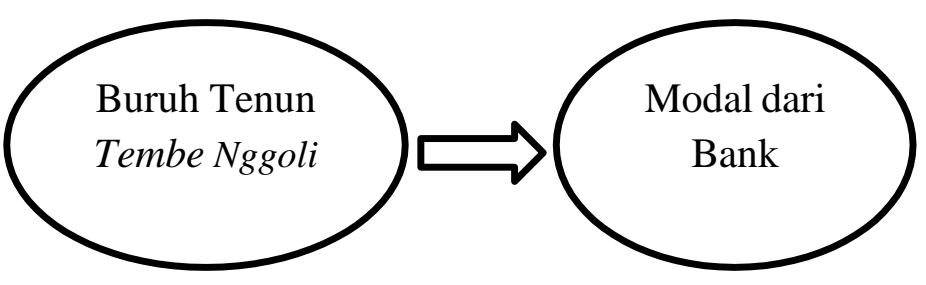

Skema 1.4

Sumber Modal dari Bank

Secara nasional pertumbuhan kredit mengalami pertumbuhan yang melambat, namun kinerja keuangan bank dalam beberapa tahun terakhir masih menunjukkan kinerja yang baik. Hal ini tercermin dari beberapa indicator (Bank Indonesia, 2014 dalam Djamil Thalib, 2016: 117), antara lain: (1) Return on Asser (ROA) bank-bank nasional memang mengalami penurunan, namun masih berada pada level yang cukup tinggi, (2) Capital Adequacy Ratio (CAR),yang menunjukkan ketahanan perbankan 
nasional, ketentuan minimum bank Indonesia sebesar $8 \%$, (3) Non Performance Loan (NPL), yang menunjukkan besarnya kredit bersama masih berada pada kisaran $2 \%$, berarti kredit pinjaman buruh tenun masuk pada NPL.

Permodalan dari perbankan, mengakibatkan masyarakat enggan berhubungan dengan pihak perbankan. Konsep perbankan ini sendiri belum sepenuhnya mampu menyentuk Usaha Mikro Kecil menengah (UMKM) seperti para pedagang di pasar tradisional atau para pelaku ekonomi kerakyatan. Ketidakmampuan perbankan menyentuk sektor ini menyebabkan pelaku pasar mengalami kekurangan sumber permodalan (Sabirin dan Dini Ayuning Sukimin, 2017: 28). Akan tetapi yang terjadi kini di lapangan ada pinjaman secara individual pelaku pekerja atau buruh tenun pada pihak bank langsung melalui Kredit Usaha Rakyat (KUR) di bank BRI yang memberikan peluang kepada penenun untuk meminjam modal secara langsung, bank tidak memberikan modal atas nama UMKM tetapi personal pekerja itu sendiri dalam hal kerajinan tenun. Beberapa masyarakat atau penenun mengambil alternatif lain yang tersedia seperti jasa pelepasan uang. Jasa melepas uang (rentenir) adalah lembaga keuangan informal yang memperoleh profil melalui penarikan bunga yang cukup tinggi dengan meminjamkan uang kepada masyarakat (Sipayung, 2011 dalam Idel Waldemi, Afvan Aquino, dan Nofrizal, 2019: 72). Hal ini terjadi jika penenun sudah ada peminjaman dari bank atau koperasi, karena kebutuhan ekonomi keluarga (kondisi keluarga miskin) maka dilakukanlah peminjaman pada rentenir.

\section{Analisis Permodalan Buruh Tenun Tradisional Bima pada Tembe Nggoli menggunakan teori Tindakan Sosial}

Max Weber menyebutkan empat tipe rasionalitas yang mewarnai perkembangan manusia. Empat tipe tersebut adalah Rasionalitas tradisional (traditional rationality) dan rasionalitas afektif (affective rationality) merupakan wujud tindakan irasional dalam diri manusia. Kemudian, rasionaliatas yang berorientasi pada nilai (value oriented rationality) dan rasionalitas intrumental (instrumental rationality) merupakan wujud keberadaan tindakan rasional dalam diri manusia (Soerjono Soekanto, 2010: 39).

Pertama, rasionalitas tradisional (traditional rationality). Rasionalitas ini bertujuannya untuk memperjuangkan nilai yang berasal dari tradisi kehidupan masyarakat. Rasionalitas ini kadangkala disebut sebagai tindakan irasional. Tindakan tradisional di kalangan penenun masih dipertahankan dalam bentuk adanya penenun yang selalu menggantungkan diri pada modal usaha dari perusahaan kain tenun Bima, padahal penenun itu sendiri menyadari pembagian jumlah keuntungan yang dirasakan (65\% harnya diperoleh perusahan kain tenun dan $35 \%$ diperoleh oleh penenun atau buruh tenun).

Kedua, rasionalitas afektif (affective rationality). Rasionalitas ini merupakan tipe resionalitas yang bermuara dalam hubungan emosi atau perasaan yang sangat mendalam, sehingga ada hubungan khusus yang tidak dapat diterangkan di luar lingkaran tersebut. Penenun atau buruh tenun yang sudah banyak dibantu oleh perusahaan kain tenun tradisional Bima, akan selalu menjaga kekerabatan antara pemilik perusahaan. Bentuk kekerabatan yang dijaga seperti tidak pernah beralih sumber yang memberikan modal usaha kepada perusahaan lain atau pemilik modal lainnya.

Ketiga, rasionaliatas yang berorientasi pada nilai (value oriented rationality). 
Rasionalitas ini merupakan sebuah rasionalitas masyarakat yang melihat nilai sebagai potensi atau tujuan hidup, meskipun tujuan itu tidak nyata dalam kehidupan seharian. Penenun atau buruh tenun akan menempatkan dirinya pada pemilik modal yang memberikan nilai harga produksi lebih tinggi daripada pemilik modal yang tawaran produksinya rendah, sehingga perusahaan-perusahaan akan selelau beradaptasi dengan harga jual produksi dari penenun. Bahkan ada beberapa pemilik modal seperti perusahaan kain tenun memberikan reward (sebuah bentuk apresiasi kepada suatu prestasi tertentu yang diberikan, baik oleh/dari perorangan ataupun perusahaan kain tenun yang biasanya diberikan dalam bentuk material atau ucapan. Dalam bentuk material memberikan uang yang lebih dari harga produksi. Sumber modal lain seperti koperasi dan bank lebih berperan pada pemenuhan kebutuhan ekonomi keluarga, dan hasil jual produksi digunakan untuk membiayai kebutuhan lainnya.

Keempat, rasionalitas intrumental (instrumental rationality). Rasionalitas ini sering disebut juga dengan tindakan atau alat. Pada tipe rasionalitas ini, manusia tidak hanya menentukan tujuan yang ingin dicapai, namun manusia secara rasional telah mampu menentukan alat (instrumen) yang akan digunakan untuk mencapai tujuan tersebut. Rasionalitas ini merupakan tipe rasionalitas yang tertinggi menurut Weber (Cuff, et.al., 1990; Johnson, 1994; Ritzer, 2000 dalam Nanang Martono, 2014: 55-56). Penenun berperan bukan sebagai penghasil produksi akan tetapi bagaimana produk yang penenun produksi dapat memiliki nilai jual lebih tinggi, dengan cara marketing produksi secara langsung ke konsumen bukan melalui perusahaan. Hal ini dapat di pasarkan langsung pada konsumen oleh penenun dengan sumber modal sendiri, melalui media sosial, sehingga memiliki nilai jual lebih tinggi. Berbeda jika penenun menjual langsung pada perusahaan kain tenun tradisional Bima, menggunakan modal sendiri dan laba yang sedikit.

\section{Kesimpulan}

Permodalan buruh tenun tradisional Bima bersumber dari modal sendiri, modal dari perusahaan/ UMKM, modal dari Koperasi dan modal dari Bank. Untuk menganalisis hasil penelitian menggunakan teori Tindakan Sosial Max Weber terdiri dari Rasionalitas tradisional (traditional rationality) dan rasionalitas afektif (affective rationality), rasionaliatas yang berorientasi pada nilai (value oriented rationality) dan rasionalitas intrumental (instrumental rationality).

\section{Daftar Pustaka}

Baskara. Wildan Yoga, 2018, Kajian Terhadap Permodalan dari Modal Koperasi Sendiri, Ditinjau dari Undang-Undnag Nomor 25 tahun 1992 Tentang Perkoperasian, Fakultas Hukum Universitas Mataram.

Creswell. John, Penerjemah Achmad Fawaid, 2012, RESEARCH DESIGN:

Pendekatan Kuantitatif, Kualitatif Dan Mixed, Pustaka Pelajar: Yogyakarta.

Darmadi. Hamid, 2013, Dimensi-dimensi Metode Penelitian Pendidikan dan Sosial, Alfabeta: Bandung.

Dendawijaya. Lukman, 2005, Manajemen Perbankan, Ghalia Indonesia, Jakarta.

Ilyas. Rahmat, 2017, Manajemen Permodalan Bank Syariah, Jurnal BISNIS, Volume 5, Nomor 2

Desember 2017.

Irfan, I. (2017). Analisis Praktik Perjudian Dalam Pilkades (Studi Pada Lima Desa Dua Kecamatan Di Kabupaten Bima). Jurnal Pendidikan IPS, 7(2), 73-83. 
Malingi. Alan, 2010, Tenun Tradisional Gedongan Lombok, Pustaka Medya: Nusa Tenggara Barat.

Mesir. Alimuddin, 2010,Mengenal Alat Tenun Bima Dompu, Mahani Persada: Nusa Tenggara Barat.

Nanang Martono, 2014, SOSIOLOGI PERUBAHAN SOSIAL: Perspektif Klasik, Modern, Posmodern, dan Poskolonial, PT. Raja Grafindo Persada: Jakarta.

Nurhasanah, N. (2017). Tradisi Hari Raju Dalam Aktivitas Pertanian Tradisional Masyarakat Desa Mbawa Kecamatan Donggo Kabupaten Bima. Jurnal Pendidikan IPS, 7(2), 84-89.

Nurhasanah, N. (2016). Masyarakat Tradisional Sambori Kecamatan Lambitu Kabupaten Bima. JUPE: Jurnal Pendidikan Mandala, 1(1), 242-248.

Nurnazmi, Syaifullah dan Ida Waluyati, 2019, Pola Hubungan antara Buruh Tenun (Tembe Nggoli) dengan Pemilik Modal di Kelurahan Rabadompu Barat Kecamatan Rana Kota Bima, Jurnal Darussalam: Jurnal Pendidikan, Komunikasi dan Pemikiran Hukum Islam, Vol. XI No.1: 242-262. September 2019, ISSN 1978-4767 (Cetak), ISSN: 2549-4171 (online).

Nurhasanah, N. (2017). Gender Dan Kajian Teori Tentang Wanita. Jurnal Pendidikan IPS, 6(2).

Nurhasanah, N. (2017). Makna Simbolik Uma Lengge Bagi Masyarakat Tradisional Sambori Kecamatan Lambitu Kabupaten Bima. Jurnal Ilmiah Mandala Education (JIME), 3(1), 201-209.

Sabirin; Dini Ayuning Sukimin, 2017,Islamic Micro Finance Melati: Upaya Penguatan Permodalan bagi Pedagang Pasar Tradisional, Economica: Jurnal Ekonomi Islam, Volume 8, Nomor 1 (2017).
Sari. Retna Atika, 2017, Pengaruh Risiko Kredit, Risiko Likuiditas, dan Permodalan terhadap Profitabilitas Perbankan (Studi Kasus pada Bank Umum Go Public yang Terdaftar di Bursa Efek Indonesia Tahun 20122015), Fakultas Ekonomi dan Bisnis, Universitas Muhammdiyah Surakarta.

Singke. N.I.MR Pahlevi Putra, 2011, SALUNGKA PA'A; Ragam Hias Kain Tradisional Masyarakat Dompu Kultur Kain Tenun Songket Dompu, CV. Rossamari Sentausa: Nusa Tenggara Barat.

Soejono Soekanto, 2006, Sosiologi Suatu Pengantar, PT. Raja Grafindo Persada: Jakarta.

Suci. Yuli Rahmini, 2017, Perkembangan UMKM (Usaha Mikro Keil dan menengah) di Indonesia, Jurnal Ilmiah Cano Ekonomos, Vol.6 No.1 Januari 2017.

Sukmadinata. Nana Syaodah, 2011, Metode Penelitian Pendidikan, PT.Remaja Rosdakarya: Bandung.

Supraba. Dito Nanda, 2010, Analisis Pengaruh Efisiensi Operasi, Kualitas Aktiva, Permodalan dan Likuiditas terhadap Profitabilitas Bank Umum di Indonesia (Studi pada Bank Umum di Indonesia Periode 20062009),

Thalib. Djamil, 2016, Intermendiasi, struktur modal, efisiensi, Permodalan dan Risiko terhadap Profitabilitas Bank, Jurnal Keuangan dan Perbankan, Vol.20 No.1 Januari 2016.

Usman, Ahmad, 2008, Mari BelajarMeneliti Cetakan I,Yogyakarta: Genta Press.

Waldemi. Idel; Afvan Aquino; dan Nofrizal, 2019, Analisis Permodalanan Pedagang pada Syariah, Ide Waldemi 7 (2019).

Winarko. Sigit Puji, 2014, Pengaruh Modal Sendiri, Jumlah Anggota dan 
Aset terhadap Sisa Hasil Usaha pada

Koperasi di Kota Kediri, Nusantara

of Research Universitas Nusantara

PGRI Kediri, Volume 1, Nomor 2,

Oktober 2014, ISSN.2355-7249.

Widoyoko. Eko Putro, 2012, Teknik Penyusunan Instrumen Penelitian, Pustaka Pelajar: Yogyakarta. 